\title{
TOMASZ MIKA
}

Adam Mickiewicz University

(Poznań, Poland)

\section{Literacy as a Context of the Medieval Bible translations into Polish}

Researchers and scholars of medieval Polish biblical translations do not have an extensive body of source material at their disposal. Apart from "The Bible of Queen Sophia" ("Sárospatak Bible") that has survived in just small fragments, what we have is just a number of psalters, few sermons and a few, luckily fairly extensive, apocryphal texts. Biblical fragments have been identified in the above available texts for years and, since quite recently, our work is additionally supported by effective and purpose-made electronic tools ${ }^{1}$. The bulk of surviving texts and annotations comprises fairly late copies, and most frequently copies made from copies of earlier texts. Moreover, supplementary additional data are scarce: as a rule, we know virtually nothing about the cultural environment in which a given text originated, the collective written output of a monastery, place or exact time of its origination. No wonder then that in our investigation into the oldest Polish translations we are bound to relate to and analyse universal relevant interpretative contexts.

It is a widely recognized fact that each and every scientific description is a resultant of a large number of attributes, namely: initial assumptions made by a researcher, adopted methodology, particular formulation of questions, limitations in access to the research object to be investigated and, finally, individual features of a researcher: his or her talent, experience and intuition.

Knowledge, being cumulative and dynamic over time, is obviously grounded in intuitive cognition of reality, earlier observations and formed opinions and views. Having said that, however, one must admit that once in a while completely new research di-

${ }^{1}$ See for example the browser: Piętnastowieczne przeklady Nowego Testamentu - elektroniczna konkordancja staropolska. Internetowa baza danych created by Mariusz Leńczuk within the grant of the National Science Centre (URL: http://stnt.ijp.pan.pl/) or a searching engine created by a team led by Izabela Winiarska-Górska Szesnastowieczne przektady Ewangelii (URL: https://ewangelie.uw.edu.pl). 
rections appear in science that help perceive a research object — in this particular case the oldest Polish translated texts — from a totally different perspective.

My primary research interests are in the area of the history of Polish syntax. Since the prevailing majority of the oldest Polish texts comprise translations from Latin, the researcher in syntax becomes in a natural way over time the translation scholar in this area. On the one hand, I am interested in the way Latin constructions were rendered in a target language, but I am equally interested in what in these translations is not an attempt to approach foreign structures slavishly, on the other. This is also why the researchers of Polish medieval syntax have recently started to appreciate more, beyond bilingualism, what has been retained in the Polish language from the period antedating the use of writing.

Insight into pre-literacy times is facilitated by two, closely inter-related, areas: language evolution and the theory of literacy. The nature of this mutual relationship is beyond the scope of the present paper though. What is interesting here is that the same researchers are typically involved in the both areas of research.

However, there is no doubt that language evolution and the theory of literacy alike already are and, I presume, will soon become even more appreciated by historians of medieval life, culture and languages, including the Polish language in the Middle Ages. In my opinion, a very significant context for linguistic research on medieval translations is provided by the theory of literacy in particular ${ }^{2}$. This theory considers the point of time at which literacy becomes a fact as an essential change resulting in a transformation of the way man thinks, perceives the world and uses language ${ }^{3}$.

This theory did not arise as a ready model and it is difficult to present its main theses and assumptions. What we encounter here is the long process of emergence and stabilization of a new study field from the works of many researchers, such as Milman Parry, Albert Lord, Eric Havelock, Harold Innis, Marshall McLuhan, Jack Goody, Walter Jackson Ong or David Olson, who, from many perspectives — originally independently from one another ${ }^{4}$ - embarked upon the same subject: the influence of the technology of word (speech, writing, print, later audiovisual and multimedia means) on a human being, society and culture. From the point of view of such considerations it is crucial that these researchers share the conviction, that the impact of writing becoming widespread in the history of societies is huge and unappreciated and leads to deep changes in mentality of every human being and in functioning of entire societies. Consequently, the psychological, communicative, social and finally anthropological aspects dominate in this kind of research.

\footnotetext{
${ }^{2}$ My article is an extension and continuation of the considerations presented in another paper (Mika 2016).

${ }^{3}$ There is no place here, however, to recall the endless and ferocious arguments on how deep the gap between orality and literacy is and whether any transitory stage in the process can be established or not.

${ }^{4}$ Independence here is understood as the absence of systematization of the assumptions and terminology and not as the lack of co-operation: one cannot deny the existence of the so-called Toronto School of Communication Theory, but in the period of its formation there were no successful efforts leading to the agreement on the common approach to fundamental research problems. On the origin, development and continuation of the Toronto School compare, e.g., Wieczorek-Tomaszewska 2010; Menachem, Watson 2007.
} 
Purposefully, I do not mention here linguistic problems: among the originators of this research direction there were no linguist (although there were philologists such as Eric Havelock) ${ }^{5}$. Despite this, almost all of the above-mentioned researchers pursued questions connected with language, often, understandably, presenting their linguistic observations in a way distant from scientific precision or metaphorically.

The two fundamental assumptions of this theory were accurately reconstructed by Aleksandra Deskur. They referred to the classical works of selected theorists of orality and literacy:

1. Writing has contributed to the emergence of an awareness of language building, which, in turn, is connected with such processes as structurization or the birth of metalanguage.

2. The written language began to function independently of its users and the non-linguistic context, thus causing its generalization and separation from the reality (Deskur, in print).

What is important to me is that in view of this theory - supplemented with available research on bilingualism (see Wenzel 1994; Schendl 2000, 2012; Adams 2003, and others) - one has to imagine a medieval scribe as belonging to two cultures simultaneously: the oral and the written one, as an illiterate man in his own vernacular language and a literate man in, for example, Latin, or written Latin to be exact ${ }^{6}$, as Walter Ong would have put it while building up the opposition: mother tongue - learned language for the similar point of time in the history of a large number of cultures (Chinese, Arabic and Latin) (see: Ong 1977: 25-35). While making a translation, a medieval writer was in a completely different situation than a bilingual translator of later years. The difference lies in the fact that he was forced to translate from a language with rich and long literary tradition, full of hierarchical syntactical structures, capable of expressing abstract notions, and using appropriate metalanguage as an important element of linguistic design. The target language though was a language spontaneously spoken, one that does not have all these properties that stem from a long-term literacy process ${ }^{7}$. These properties are to be recognized and studied by the theory of literacy. Even though the theory has been developing for a long time and is already internally diversified and crit-

5 The same can be said about the Toronto School and its origins: "In program assumptions, the Toronto School emerges from a critical concept of modern communication by $\mathrm{H}$. Innis and his disciple M. McLuhan who studied the role and influence of the media upon society with regard to economic, political, anthropological and mental aspects" (Wieczorek-Tomaszewska 2010: 2).

${ }^{6}$ As Alderik Blom writes: 'literacy meant first and foremost Latin literacy. However [...] there was a developing role for the vernaculars' (Blom 2017: 3).

${ }^{7}$ Carolyne Muessig asks: 'Why did scribes like Raoul de Châteauroux preserve sermons in Latin and not the vernacular; and why did sermon composers write in Latin and not the vernacular? One answer is that the vernacular, before the fourteenth century, provided an underdeveloped written framework for recording the spoken sermon, while Latin provided a well-established grammatical structure for the recording of homiletic language. This is partly related to the formation of preachers and scribes who were responsible either for the composition of homilies or for the copying of them. Many of these men were well-educated theologians, priests, and monastic thinkers; they were imbued with religious instruction via the Latin language'. (Muessig 2010: 270). 
ically examined in literature, regrettably, its accomplishments are seldom penetrated by linguists - at least as far as the Slavic languages are concerned.

Recognition of the theory of literacy as an important context for research on the oldest Polish translations of biblical texts, or more broadly speaking, religious texts in general, makes it possible to step outside the following pattern of thinking: faithful translation - adaptive translation, and helps us understand better the vast extent of challenges translators of Christian books into vernacular languages in Middle Ages were confronted with. Finally, it allows us to attempt to provide an answer as to why, despite such a small body of available surviving texts, we have a chance to see so many ways of rendering a given Latin structure: "translators had to wend their way between literal transcription and the requirements of another linguistical setting" (Menache, Horowitz 1996: 327).

From this point of view, the oldest Polish translations of religious and ecclesiastical texts can be viewed as an area of incessant rivalry and mutual influence between structures typical for the pre-literacy language and established structures shaped by writing and reading practices. Showing this phenomenon in the perspective of the theory of literacy is the aim of my article.

One of the strongest tendencies in the history of syntax in the Slavonic languages is the tendency to autonomisation of language. Here, the tendency is generally understood to refer to a direction of change. Autonomisation is then based, metaphorically speaking, on making a particular break from reality (see: Krążyńska, Mika, Słoboda 2015).

This direction of change leads from a strict interlocking of language with extra-linguistic reality (language co-creates an event), to a gradual detachment of language from extra-linguistic reality (language becomes the creator of its own, linguistic reality). This tendency abounds in its manifestations. The most important include: gradual appearance of abstract words, frequently coined $a d$ hoc, more and more common break with the natural chronology in complex sentences with coordinating conjunctions or attempts to name the reality of language and text. Unquestionably, no translation of religious texts would be possible without these skills being adequately developed.

The basic form of rendering events for a pre-literacy language is to recount them in exactly the same sequence in which they have happened. This is additionally accompanied by an expression of the basic relationship: the sequence in time and interrelated resultant effects.

In sentences that retain sequence of events compliant with extra-linguistic reality it happens every so often that the component actions of a given event are named in detail, e.g.:

A uźrawszy ją i obrocił się na stronę a wstawszy przeciw jej i przywitał ją barzo łaskawie rzekąc:

'Witaj, ma miła przyjaciołko!' (and (he) saw her and turned towards her and stood up in front of her and greeted her very warmly saying: 'welcome to you my good friend') (Keller, Twardzik 2000: 136). 
Sentences constructed as the above exemplary sentence that show step by step consecutive events abound in Old Polish apocryphal texts in places where the original Latin sources prompt a rather simplified form of the event content, or include hypotactic structures in which the event that is the head element of an utterance is first named and then, by using the subordination of one syntactic unit to another, the factors that condition this event are added.

The consequence of this chronological approach towards the expressed content is a major preponderance in Old Polish of paratactic structures that do not involve subordination, in particular conjunctive and resultant, over others. Within subordinate structures, in turn, the set of sentences subordinate - superordinate dominates over the superordinate - subordinate system, since it is just the former that renders extra-linguistic sequence of events in language: first it is indicated what occurs in reality as first, then what follows is presented.

Obviously languages that are deeply rooted in literacy, such as biblical Latin, frequently tend to avoid this particular way of rendering events by using other constructions. More complex and complicated relations are expressed, while insignificant events are ignored, but, first of all, the chronological order is discarded. Old Polish writers, however, attempt to retain and render the textual sequence by introducing new structures in an ever-growing number of experiments. Occurrences where a given fragment of a text is available in a larger number of examples are of particular value.

For example, a well-known fragment of The Vulgate (Christ's sermon upon the mount, Matthew 5. 4): 'Beati, qui lugent, quoniam ipsi consolabuntur (Blessed are they that mourn: for they shall be comforted)' was rendered in medieval Polish in a number of ways:

1. 'Ci, jiż żałują, są błogosławieni, bo będą ucieszeni (those who mourn are blessed, because they shall be comforted' 8

2. 'Błogosławieni, jiż żałują, bo oni będą ucieszeni (Blessed who mourn for they shall be comforted)' (Wydra, Belcarzowa, Twardzik 2008: 37)

3. 'Błogosławieni, jiż są w żeli, bo oni będą ucieszeni (Blessed who are in sorrow, for they shall be comforted)' (Wydra, Belcarzowa, Twardzik 2008: 13)

4. 'Błogosławieni, jiż żałość mają albo łkają, bo oni będą ucieszeni (Blessed who have sadness or sob for they shall be comforted)' (Wydra, Belcarzowa, Twardzik 2008: 21)

5. 'Błogosławieni, ktorzy płaczą, bo ci będą uwieseleni (Blessed who weep as they shall be content)' (Keller, Twardzik 1998: 522).

The first four translations come from just a single sermon ("All Saints Day Sermon" from the manuscript collection at the Chapter Library in Prague) the subject of which is beatitudes, the last one is from the largest Polish apocrypha, "Rozmyślanie przemyskie" (The Przemyśl Meditation). The reminiscence of pre-literacy is most visible in the first translation: ' $\mathrm{Ci}$, jiż żałują, są błogosławieni, bo będą ucieszeni (those who mourn are blessed, because they shall be comforted)'.

${ }^{8}$ LMC, MS D. LII, fol. $175^{\text {r }}$. Transcription mine. 
What we experience here is, contrary to the Latin original, a return to a natural chronology of named events (actions): first they mourn, then shall be blessed and, finally, shall be comforted. This particular order of events implies the following relations: mourning triggers beatitude, beatitude results in comfort ${ }^{9}$. All spiritual (emotional) states are action named using verbs or constructions with verb forms.

Havelock writes on pre-literate language:

All subjects of statements have to be narrativised, that is, they must be names of agents who do things, whether actual persons or other forces which are personified. The predicates to which they attach themselves must be predicates of action or of situation present in action, never of essence or existence. The formula 'Honesty is the best policy' is a creature of literate speech, of documented speech. In orally preserved speech, this becomes 'An honest man always prospers'. More likely still, instead of being isolated in a maxim, the man's performance is incorporated in a story where he performs honestly (or fails to perform honestly) (Havelock 1986: 76).

The above discussed translation of the third beatitude resembles just this particular state of language development: actions are expressed with verbs (or verbal constructions), their consecution is consistent with the sequence of events. They are not, though, expressed, what might be expected, by a paratactic structure. Following the Latin pattern, the expression (utterance) has a hypotactic structure, while the Latin function words (qui, quoniam) are rendered by Polish (jiz, bo). In fine details the compound sentence is structured differently than the one in the source language ${ }^{10}$, namely, a parenthesis is needed to preserve the sequence of events without violating hypotaxis (hypotactic syntax):

Konsekwencją takiego ujęcia treści jest przewaga struktur współrzędnych, zwłaszcza łącznych i wynikowych, nad innymi. Natomiast w obrębie struktur podrzędnych nad układem nadrzędno-podrzędnym przeważa układ podrzędno-nadrzędny, gdyż właśnie on oddaje w języku pozajęzykową kolejność zdarzeń: najpierw mówi się o tym, co w rzeczywistości zachodzi jako pierwsze, potem o tym, co następne. (As the consequence within subordinate structures, it is the subordinate-superordinate system that prevails over the superordinate-subordinate system, because it is the former that renders extralinguistic sequence of events in language: first what happens in reality is presented, then what follows in a sequential order) (Krążyńska, Mika, Słoboda 2015: 96).

In the next translation: 'Błogosławieni, jiż żałują, bo oni będą ucieszeni (Blessed are those who mourn for they shall be comforted)', which is a precise translation of the original Latin version, of note are two differences relative to the previous translation.

${ }^{9}$ On a side note: the cause and effect relationships are the derivative of the sequence of tense: it might have been so that it is just the way they were expressed that ushered in the shift from additivity to, first, parataxis, and then from parataxis to hypotaxis.

${ }^{10}$ In detail, the point can be explained as follows: the superordinate clause (' $\mathrm{Ci}$ sa błogosławieni (Those are blessed)') is separated after the pronominal subject with a relative clause (' $\mathrm{Ci}$, jiż żałują, są błogosławieni (Those who mourn are blessed'): as a result the naming of the earlier action ('płaczą' [mourn]) expressed in a subordinate clause is preceded by the naming of the following action expressed by the main clause (or, to be precise, by a verbal group in the clause). 
Instead of the construction with the auxiliary verb: 'są błogosławieni' (are blessed) we have the participle: błogosławieni (blessed); moreover the participle is placed, just as in the original source langue, at the very beginning of the sentence. The event content is only implied (using the expression of action by a nominal predicate) while the action is not expressed by the verb.

The next two translations include elements that are even closer to remote literacy. Interestingly enough, they overstep in this regard the Latin pattern (the Polish language becomes even more 'learned'): in place of 'jiż żałują (who mourn)', two constructions with auxiliary verb, preposition and abstract noun appear (żal, żałość [sorrow, sadness]), 'są w żeli (are in sorrow)' and 'żałość mają (have sorrow)'. Still, differently and again with abstracts, the same content is expressed in the Polish gloss in other medieval text: 'lugent — cirpią smętek (suffer from saddness)' (Vrtel-Wierczyński 1953: 115).

All this seems to confirm the observations that have been earlier made by theoreticians of literacy. Havelock writes:

One law of narrative syntax in oral poetry, noted by specialists, takes the form of parataxis: the language is additive, as image is connected to image by 'and' rather than subordinated in some thoughtful relationship. But the parataxis habit is only the tip of the iceberg or (a better metaphor) the set of clothing which contains the living body of the language. This living body is a flow of sound, symbolizing a river of actions, a continual dynamism, expressed in a behavioral syntax, or (if the language of modernistic philosophy is preferred) a 'performative' syntax. Recognition of it is essential to the formation of a true general theory of primary orality, one which also prepares us to confront a profound transformation that has since occurred in the non-performative language we often use today (Havelock 1986: 76-77).

It is worth noting that the above cited translations come from just a single text ${ }^{11}$. So, the earlier observation of a particular rivalry (competition) get its further confirmation and is further attested - there are constructions that represent its different chronological layers concurrently occurring in language. This is even more intensified in texts that discuss one event or a pericope only containing a section from the Gospels that is repeatedly referred to, like in mentioned texts. A variety of synonymous constructions and vocabulary in both texts is even more augmented by the fact that they are available in heavily glossed copies ${ }^{12}$, while these glosses are introduced into the text without any graphical marking (most frequently they are simply preceded with a function word such as 'to jest [that is]' or 'albo [or]'). One can also find in the sentence un-

${ }^{11}$ It should be observed that the construct 'być w żeli' is to be found exclusively in Kazanie praskie.

12 This issue has been addressed with regard to both mentioned texts. Kazanie praskie is discussed within this context by Roman Mazurkiewicz and Paweł Stępień, among others: "the numerous glosses introduced to the text go are indicative of the fact that it is a copy of an earlier copy, dated by the researchers for about 1430" (Mazurkiewicz, Stępień 2007: 202). The authors indicate appropriate examples of these glosses: 'błogość or błogosławność', 'błogość or błogosławieństwo', 'ducha or dusze', 'żałość mają or łkają', 'prze mowę or prze słowo', 'spokojni or pokojący', 'złobliwością or na złobliwości', and 'przeciwność or prześladowanie'. The glosses in "Rozmyślanie przemyskie" are discussed by a number of researchers, cf.: Gesner 2011; Mika 2013; 2015; Mika, Twardzik 2012; Twardzik 1994; Rojszczak--Robińska 2011. 
der scrutiny from the sermon traces of a genetic multilayered structure ${ }^{13}$ : 'Błogosławieni, jiż żałość mają albo łkają, bo oni będą ucieszeni (blessed are those who have sorrow or weep)' (Wydra, Belcarzowa, Twardzik 2008: 21).

In one relative clause: 'jiż żałość mają albo łkają (who have sorrow or weep)' two ways of naming the event are combined: the prevalent abstract expression in this sermon: 'mają żałość (have saddnes, sorrow)' and a specific, incidental, originally introduced in a gloss and then incorporated into the main body of the text: 'łkają (sob)'14.

Similar examples of rendering a Latin structure - even in just one Polish text in a number of ways can be quoted in numbers. On might have an impression at times that Old Polish writers were particularly fond of multiplying available constructions, that what was important for them was the meaning that had to properly rendered, whereas the superiority of content over form allowed structural variations to be performed at will. Hence two questions can be raised here: were all these attempts conscious and were they purposeful? Both can be answered positively ${ }^{15}$.

In one of the oldest Polish medieval texts from a collection of sermons commonly known as "Kazania świętokrzyskie" (The Holy Cross Sermons), that is in "Sermon IV" (Christmas Day Sermon), its author constructs several times syntactically identical parallel sentences. All of them have the same word order (verb + pronoun + noun + adjective), but different from the Latin original (noun + possesive pronoun + verb + pronoun):

idzie tobie krol prawdziwy (The righteous 'honest' king is coming unto thee)

idzie tobie krol wieczny (The eternal king is coming unto thee)

idzie tobie krol ubogi (The indigent king is coming unto thee)

idzie tobie krol śmierny (The humble king is coming unto thee).

These are sentences - refrains (reruns) that begin and conclude each of the sections of the elaborated body of this sermon. In the conclusion included in Christmas Day Sermon we then read 'a przeto <mowi ta to sło>wa: Krol twoj idzie tobie, iżby ty s nim na wieki wiekom krolewał (for he says these very words: Your King is coming unto you for you to rule with him for ever and ever)'.

It is plain to see that at the coda of the sermon the writer copies in Polish the word order of the biblical Latin sentence which, most probably (the beginning of the sermon has not survived to our times due to the damage to the manuscript), was the sermon topic: 'rex tuus venit tibi (your king is coming unto you)' (Matthew 21. 5, Zacharias 9. 11). We might say then that this kind of a presentation was a particular game for two languages in which the writer invited the intellectually accomplished receiver to distin-

13 'The multi-layer genetic structure of the text is a definition of a very complex issue of the relationship between a text, that in the version that has been preserved to our times constitutes the object of direct philological study, and the "primary", "original" text, a "ancient primary source" and/or its successive versions preceding the text available for study', see Mika 2018.

${ }^{14}$ The verb ' $f k a c$ ' is to be found in the text only once: in the discussed gloss only.

${ }^{15}$ This is also attested by the accounts on metatextual nature (significance) (such as the commentary to a translation of the Lord's Prayer, see Masłej 2015, 2016) and the rhetorical measures in which different translational possibilities are used. 
guish for himself references to Latin and highlighted essential content (Mika 2006: 15). "Kazania świętokrzyskie" are believed to have been a collection of exercises and examples for preachers. It can thus be assumed that its author took it for granted that the prospective receivers - in this case people with a substantial knowledge of Latin would easily notice the rhetorical purpose in the use of different word order.

The above example imminently prompts a question about literality, the question that cannot be evaded in literacy theory and is repeatedly highlighted. In oral culture a 'verbatim' quote meant an expression of the same content, in the culture of literacy - the expression of the same content by means of the same words. Thus understood 'literality' has grave consequences and is a factor that stimulates future changes, including a possibility to employ a quote; complex syntactical structures are needed to make an inclusion of text within text (structures with other structures) possible, such as direct and indirect speech. An application of mnemotechnical devices such as figures of speech, rhythm, poetic mood in utterances, all had made it possible to gather and convey contents that were culturally significant, but it was their verbatim memorization that was greatly facilitated by the use of writing. By having access to the original version of a text to be conveyed it is possible to control memory far better. Olson writes: 'Verbatim memorization seems a uniquely literate activity' (Olson 1996: 101).

A medievalist is hard to be of the same belief as Olson that "the concept "verbatim" [exact copying — T. M.] is a relatively modern word coined only in the fifteenth century' (Olson 1996: 106). There are simply far too many translated verbatim citations in vernacular texts. It is also important to remember about the mnemonic system of learning in medieval ages. Formulization, so typical for orality, also yielded results that were close to literality. However, there is no doubt that:

Memorisation without writing, is only misleadingly called 'verbatim'. [...] Verbatim memory of longer texts does not occur unless there is a written text against which memory can be checked. Without such a verbatim record, disputes about particular wordings are likely to be unresolved because recall of wording is strongly influenced by the semantic or meaning properties of the text (Olson 1996: 107).

This particular path to literality is brilliantly shown and attested in Old Polish texts. An examination of the ways such constructions as ACI (accusativus cum infinitivo) or NCI (nominativus cum infinitivo) were translated into Polish medieval translations of very complex nominal groups clearly show the tendency in the change: from expressing the same content in a number of ways, through rendering the same context with the same words, to, finally, rendering the same content in the same words with the same grammatical forms.

In the oldest, nearly 850-page long, Old Polish apocrypha, i.e. "Rozmyślanie przemyskie", only few strictly mapped ACI constructions have been found, whereas in the apocrypha "Rozmyślania dominikańskie" (Dominican Meditations), eight times smaller than "Rozmyślanie przemyskie", there is a dozen or so of them. The former is several dozen years older than the latter and originated in the transition period from late Middle Ages and Renaissance. 
The most important part of the body of the Latin original of the older apocrypha, "Rozmyślanie przemyskie", which is the treatise "Vita beate virginis Marie et Salvatoris Rhytmica" the ACI constructions abound and are often repeated in parallel systems.

For example:

Herbas atque gramina de terra pullulare

Vidit et se frondibus arbores ornare

Et cum multi fructibus flores germinare

Et pro pullis vidit aves nidos comportare (Keller, Twardzik 1998: 5).

Which is rendered in the Polish apocrypha as:

uźrała zioła a trawę rozkosznie idący z ziemie ((she) saw herbs and grass nicely sprouting from the earth)

uźrała też drzewa rozkosznym listem okraszona ((she) also saw trees garnished with nice leaves)

ptaki uźrała, a ony gniazda niosą ((she) saw birds and them building their nests)

gdzie by swe dziatki mieli (where (they) would have [will have ${ }^{16}$ ] their children) (Keller, Twardzik 1998: 4).

Disregarding the syntactical details for the time being, we can say that the author used a complex participial nominal group twice in place of the ACI construction, once, a compound sentence, and once a subordinate clause that expresses the additional action (expanding clause).

In particular, the translation of the ACI syntactic construction using compound sentences and multiple complex sentences (she saw birds and them building their nests, where (they will have) their children) is deeply rooted in pre-literacy language: the action of seeing is expressed in the past tense, the action seen at its point of completion is expressed in the present tense, whereas the action that results from the previous action is in the future tense. Mary came and saw that the birds were carrying sticks to refurbish nests for the current season in which they would have their children. Note that the Latin original does not say anything about the instance of having children: there are only nests for children (pro pullis) mentioned, which is to say: their future children. This construction - the ACI with a prepositional phrase that implies additional content had been properly understood by the writer who was knowledgeable and well-versed in Latin, though he was not able to find an appropriate and corresponding structure in the Polish language: what he decided to do was to choose a narration, typical for spoken language, broken up into a presentation of the sequence of events.

So the content has been rendered, but the form has not been translated. The translator, however, felt obliged to render the rhetorical value (in Latin, four rhymed ACI constructions - set in pairs and introduced twice by the verb vidit (see)). Instead, he managed to reach the required artistic expression using other measures: he repeated initially the same verb ('zobaczyła') three times, moving the secondary predicates on to the end of syntactic elements. To make this parallelism three-element, he left out one

\footnotetext{
${ }^{16}$ Future action expressed by coniunctivus (conditional mood): where (they) could have their children.
} 
of the Latin segment ('Et cum multi fructibus flores germinare'). He also did not translate the specific name of the tree (arbor - fig tree), either.

In conclusion, from this perspective, a strong tendency in the Old Polish syntax, namely structurization, is clearly observable. Paradoxically, the course does not lead from imitation of Latin structures to the richness of vernacular structures. What happens is just the opposite, the older Polish texts manifest more abundant vernacular structures, rooted in spoken language, in translations. The closer to the twilight of the Middle Ages, the more influenced they become by the propagation of writing in the culture of translation, learned and literate structures. It is only when they are present in a language that proper conditions for a faithful, literal translation are truly met. However, as a rule, in the majority of the Old Polish texts, one construction is rendered in a number of ways. Older layers coexist with earlier ones.

The reference to the theory of literacy allows us to understand why the Old Polish texts (and language) are dominated by the chronological approach towards the expressed content, what is the source domination of hypotaxis over parataxis, and why the set of subordinate-superordinate sentences dominates over the superordinate-subordinate one. These facts were difficult to explain on the basis of the existing linguistic theories. They are an essential part of the process of vernacularization and constitute an important context for research on medieval translations into vernacular languages.

In addition, the confrontation of the element of a pre-literacy language with a 'learned' language does not necessarily lead to immediate act of copying. It is the consciousness of native language, influenced by a foreign pattern, that has to be established first.

As a kind of a post scriptum to my article, I would like to make an observation that should become a subject for a separate paper. Polish medieval texts include a great number of words and unique constructions. Traditionally, this is explained by the fact that only a small percentage of extant Polish medieval literature has survived. What is striking though is that the higher artistic standing (position) of a work, the more elements that have not been used elsewhere in its vocabulary. It appears that the approach to the Polish language substantiated by the writers with the highest skills and the highest language awareness was often very flexible and highly creative. The contemporary language, pushing itself forward towards literacy and still being in a stage far from standardisation (not to mention normalisation), forms a pliable material, very susceptible to transformations. We all know that at any moment of time language is redundant. Right at the beginning of its literary functioning though, its redundancy seem to be at the highest point.

\section{Bibliography}

Adams J.N., 2003, Bilingualism and the Latin Language, Cambridge.

Blom A., 2017, Glossing the Psalms. The Emergence of the Written Vernaculars in Western Europe from the Seventh to the Twelfth Centuries, Berlin-Boston. 
Deskur A., in print, O potrzebie wykorzystywania terminów z zakresu teorii oralności i piśmienności w językoznawstwie. Termin upiśmiennienie, [in:] Staropolskie Spotkania Językoznawcze, vol. 3: Terminy w językoznawstwie diachronicznym i synchronicznym, ed. T. Mika, D. Rojszczak-Robińska, O. Ziółkowska, Poznań.

Gesner A., 2011, Glosy w Rozmyślaniu przemyskim. Wyniki analizy formalnej i perspektywy badań, Kwartalnik Językoznawczy 3, pp. 89-96.

Goody J., Watt I., 2007, Następstwa piśmienności, transl. J. Jaworska, [in:] Almanach antropologiczny. Temat: oralność/piśmienność, ed. A. Mencwel, Warszawa, pp. 33-73.

Havelock D., 1986, The Muse Learns to Write: Reflections on Orality and Literacy from Antiquity to the Present, New Haven-London.

Innis H., 2008, The Bias of Communication, Toronto.

Keller F., Twardzik W., 1998, 2000, 2004 (ed.), Rozmyślanie przemyskie: Transliteracja, transkrypcja, podstawa łacińska, niemiecki przekład, 3 vols, Monumenta Linguae Slavicae Dialecti Veteris Fontes et Dissertationes, 40, 42, 48, Freiburg i Br.

Krążyńska Z., Mika T., Słoboda A., 2015, Składnia średniowiecznej polszczyzny. Część I: Konteksty — metody - tendencje, Poznań.

Masłej D., 2015, O wyjątkowym średniowiecznym komentarzu do tłumaczenia modlitw, LingVaria 2 (20), pp. 221-234.

— 2016, Modlitwa Pańska w polskim średniowieczu. Znad staropolskich rękopisów, Poznań.

McLuhan M., 2017, Galaktyka Gutenberga. Tworzenie człowieka druku, transl. A. Wojtasik, ed. G. Godlewski, K. Kukiełko-Rogozińska, Warszawa.

Mazurkiewicz R., Stępień P., 2007, Źródła i konteksty Kazania praskiego (rekonesans), [in:] Amoenitates vel lepores philologiae, ed. R. Laskowski, R. Mazurkiewicz, Kraków, pp. 202-221.

Menache S., Horowitz J., 1996, Rhetoric and Its Practice in Medieval Sermons, Historical Reflections 22, pp. $321-350$

Menachem B., Watson R., 2007, The Toronto School of Communication Theory: Interpretations, Extensions, Applications, Toronto.

Mika T., 2006, Tajemnice Kazań świętokrzyskich, Teraz. Świętokrzyski Miesięcznik Kulturalny 1, pp. 14-15 .

- 2013, Genetyczna wielowarstwowość i złożoność tekstów staropolskich a ich badania historycznojęzykowe. Rekonesans, Biuletyn Polskiego Towarzystwa Językoznawczego LXVIII, pp. 131-145.

— 2015, Problemy z Rozmyślaniem przemyskim. Formułowanie sądów ogólnych a wielowarstwowość średniowiecznego tekstu, LingVaria, special number, pp. 87-104.

— 2016, Początki polskiego języka religijnego a upiśmiennienie języka polskiego. O możliwości nowego spojrzenia na staropolskie przekłady religijne przez pryzmat badań nad piśmiennością, [in:] Święte księgi judaizmu, chrześcijaństwa i islamu w słowiańskim kręgu kulturowym, [in:] Prace dedykowane Profesorowi Czesławowi Łapiczowi, vol. 3, ed. M. Krajewska, J. Kulwicka-Kamińska, A. Schulz, Toruń 2016, pp. 63-76.

- 2018, The oldest Polish texts. New methods and new research issues in Polish historical linguistics', [in:] The oldest linguistic attestations and texts in the Slavic languages, ed. A. Kapetanović, Vienna, pp. 212-233.

Mika T., Twardzik W., 2012, Jak zagadkowe cztery tytuły rozdziałów w Rozmyślaniu przemyskim pozwalają wyobrazić sobie jego zagubiony autograf, [in:] Schnittpunkt Slavistik. Ost und West im wissenschaflichen Dialog. Festgabe fur Kelmut Keipert zum 70. Geburstag, vol. 3: Vom Wort zum Text, ed. by I. Podtergera, Bonn, pp. 359-375.

Muessig C., 2010, The Vernacularisation of Late Medieval Sermons: Some French and Italian Examples, [in:] Medieval Multilingualism. The Francophone World and Its Neighbours, ed. Ch. Kleinhenz, K. Busby, Turnhout, pp. 267-284.

Olson D.R., 1996, The World on Paper: The Conceptual and Cognitive Implications of Writing and Reading, Cambridge. 
Ong W.J., 1977, Interfaces of the word: Studies in the Evolution of Consciousness and Culture, Ithaca.

— 2011, Oralność i piśmienność. Słowo poddane technologii, transl. J. Japola, ed. 2, Warszawa.

Prague, Library of the Metropolitan Chapter of Prague, MS D. LII

Rojszczak-Robińska D., 2011, Trudne miejsca Rozmyślania przemyskiego. Problem glos, [in:] Zbliżenie.

Literatura - kultura — język — translatoryka, ed. I. Fijałkowska-Janiak, Gdańsk, pp. 213-220.

Schendl H., 2000, Linguistic aspects of code-switching in medieval English texts, [in:] Multilingualism in Later Medieval Britain, ed. D.A. Trotter, Cambridge, pp. 77-92.

- 2012, Literacy, Multilingualism and Code-switching in Early English Written Texts, [in:] Language Mixing and Code-Switching in Writing. Approaches to Mixed-Language Written Discourse, ed. S. Mahootian, M. Sebba, C. Jonsson, New Jork, pp. 27-43.

Tremblay G., 2012, From Marshall McLuhan to Harold Innis, or From the Global Village to the World Empire, Canadian Journal of Communication 37 (4), pp. 561-575.

Twardzik W., 1994, Glosy w Rozmyślaniu przemyskim, Teksty Drugie 3, pp. 155-165.

Vrtel-Wierczyński S., 1953 (ed.), Kazania gnieźnieńskie: Podobizna, transliteracja, transkrypcja, Zabytki Języka i Literatury Polskiej 2, Poznań.

Wenzel S., 1994, Macaronic Sermons. Bilingualism and Preaching in Late-Medieval England, Michigan. Wieczorek-Tomaszewska M., 2010, Szkoła z Toronto dawniej i dziś. URL: http://www.ktime.up.krakow.pl/ ref2010/wieczorek.pdf

Wydra W., Belcarzowa E., Twardzik W, 2008 (ed.), Kazanie na dzień Wszech Świętych (tzw. praskie), Poznań.

\section{SUMMARY}

\section{Literacy as a Context of the Medieval Bible translations into Polish}

Keywords: theory of literacy, Old Polish language, translation in the Middle Ages.

Słowa kluczowe: teoria piśmienności, język staropolski, tłumaczenie w średniowieczu.

The author argues that a very significant context for linguistic research on medieval translations is provided by the theory of vernacular literacy which can facilitate new insights into the oldest Polish texts. Its inclusion in the theoretical framework makes it possible to detect that structures deeply rooted in pre-literacy co-existed with structures typical for literate language. The author proposes to imagine the medieval translator as an illiterate man in his vernacular language and a learned one in Latin. The article provides an analysis of structures from Kazanie praskie, Kazania świętokrzyskie and Rozmyślanie przemyskie in the context of theory of literacy. 